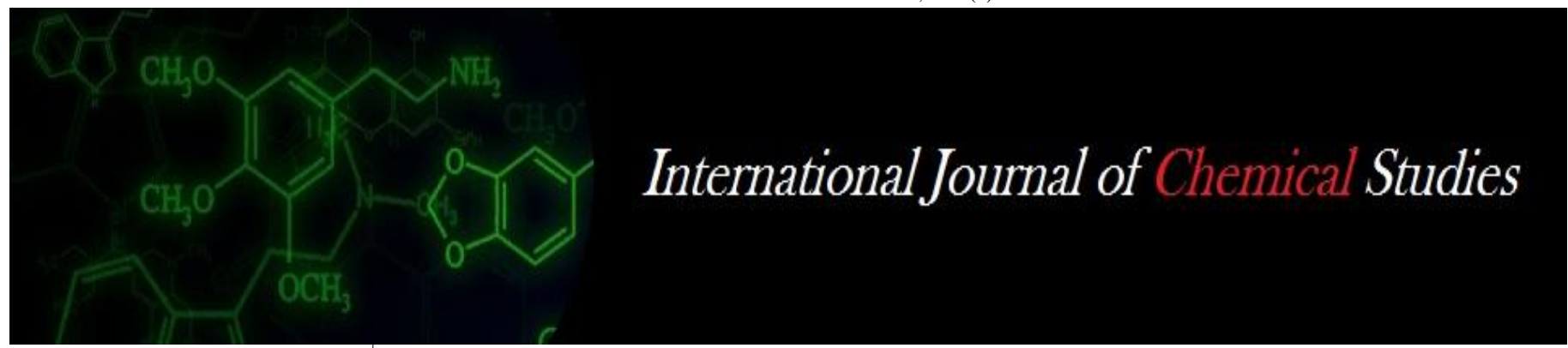

P-ISSN: 2349-8528

E-ISSN: 2321-4902

www.chemijournal.com

IJCS 2020; SP-8(2): 01-03

(C) 2020 IJCS

Received: 02-01-2020

Accepted: 04-02-2020

Jitendra Ojha

Faculty of Agricultural Sciences

\& Allied Industries, RAMA

University, Kanpur, Uttar

Pradesh, India

Yashi Mishra

CSA University of Agriculture

and Technology, Kanpur, Uttar

Pradesh, India

Deepankar Tiwari

CSA University of Agriculture

and Technology, Kanpur, Uttar

Pradesh, India
Corresponding Author: Jitendra Ojha

Faculty of Agricultural Sciences

\& Allied Industries, RAMA

University, Kanpur Uttar

Pradesh, India

\section{Analysis of factors in production and marketing of pulses: A review}

\section{Jitendra Ojha, Yashi Mishra and Deepankar Tiwari}

DOI: https://doi.org/10.22271/chemi.2020.v8.i2at.9245

\begin{abstract}
India has to shift its focus from production of cereals to pulses regarding tackling the issue of malnourishment as the fact reveals that every third malnourished person is Indian. Although being one of the largest pulses crop cultivating country in world. The major problems faced by cultivators are lack of adequate knowledge in package of practices in pulses. the farmers also faced the minor problems of low productivity of pulses, non-availability of HYV seed and credit. The problem of labour availability is not so prominent and the quality of land is good for the cultivation of pulse crops. The major marketing problems are Price fluctuation, Lack of processing unit in local area, Lack of processing unit in local area Lack of cooperation among farmers, Higher transportation charges. Way forward regarding this problems is improved quality standards, Value demands, and Processing and Grading of Pulses.
\end{abstract}

Keywords: marketing of pulses, pulses crop, processing and grading of pulses

\section{Introduction}

Pulses are important component of Indian diet still it is ironical that India has to import pulses. In post-independence era, India has experienced many changes in agricultural development and green revolution was most spectacular. Food grains production increased manifold due to increase in irrigated area, cropping intensity, consumption of chemical fertilizers, insecticides, pesticides, high yielding varieties of seeds and management practices. Although, being one of the largest pulses crop cultivating country in the World, pulses' share to total food grain production in India is only about $6 \%-7 \%$ in the country. The increasing mismatch between production and consumption of pulses has resulted in larger imports of pulses in recent years. The country was importing merely 0.17 million tons in past. Moreover, the lack of an assured market is one of the major issues in the poor performance of pulses. Pulses constitute an essential part of the Indian diet for nutritional security and environmental sustainability.

\section{Materials and method}

The study is split into two parts

1. Economics of production.

2. Study of marketing.

\section{Sampling techniques are adapted at three levels}

1. Selection of block.

2. Selection of villages.

3. Selection of cultivators.

The methods that are used in analysis are: average, correlation coefficient, producer's share in consumer rupee, compound growth rate.

\section{Production constraints faced by producers}

The root cause of decline in production of pulses is lack of adequate knowledge in package of practices in pulses. the farmers also faced the minor problems of low productivity of pulses, non-availability of HYV seed and credit. The problem of labour availability is not so prominent and the quality of land is good for the cultivation of pulse crops, it is also observed that the constraints in production of pulses were lack of knowledge about recommended dose 
of fertilizers, lack of improved variety seeds, lack of knowledge of recommended practices and lack of irrigation facilities.

\section{Marketing constrains faced by producers}

1. Price fluctuation was ranked as the most important constraint among the pulse growers with mean score value of 61.98 followed by small quantity of marketable surplus.

2. Market news and intelligence were not available for most of farmers which got rank III with a score of 56.02.

3. Fourth major constraint reported by the pulse growers was involvement of large number of intermediaries in the marketing which resulted in decrease of farmer's share in consumer's rupee

4. Lack of proper scientific storage facilities at reasonable price

5. Prices offered in the markets were not remunerative

6. Lack of processing unit in local area

7. Lack of cooperation among farmers

8. Higher transportation charges.

\section{Other factors affecting the production of pulses}

\section{Soil}

Being leguminous crops, all the above-mentioned pulses (except tur) help in restoring soil fertility by fixing nitrogen from the air. Therefore these crops are mostly grown in rotation with other crops.

\section{Climate}

Pulses need less moisture and survive even in dry conditions.

\section{Rainfall}

Generally pulses require low rainfall but Indian agriculture is a gamble of monsoon, so uncertainties in rainfall causes sharp decline in production.

\section{Factors affecting the marketing of pulses}

\section{Population}

India being highly populous country is highly deficient in protein content in their diet, and their stomach is filled with majorly cereals. Demand of pulses is really high in most of parts of country. Pulses are the cheapest source of proteins and Indians fulfill 20 to 30 per cent of their protein requirement from pulses, rich in calcium and iron also. Per capita net availability of pulses in India, however, has reduced from $69.0 \mathrm{gm} /$ day to $47.2 \mathrm{gm} /$ day as against WHO recommendation of $80 \mathrm{gm} /$ day. High population requires a efficient marketing channels.

\section{Distribution of land holding}

Small land holdings is the major constrains in production of pulses.

\begin{tabular}{|c|c|c|c|}
\hline Land holding & Beneficiaries & Non beneficiaries & Total \\
\hline Marginal & 8.33 & 10 & 9.17 \\
\hline Small & 48.33 & 65 & 56.67 \\
\hline Semi medium & 36.67 & 23.33 & 30 \\
\hline medium & 5 & 1.67 & 3.33 \\
\hline large & 1.67 & 0 & 0.83 \\
\hline
\end{tabular}

\section{Way forward of improving production of pulses}

1. Pulse crops should be introduced as an inter-crop/mixedcrop/rotational crop in the cropping system. Some financial incentives should be given to the farmers for bringing more area under pulses.

2. There is a need to aware the farmers about various schemes like NFSM- Pulse, under which Government provides incentives to the farmers to enhance production of pulses

3. High yielding varieties of pulses suited to dry farming/moisture-stress conditions need to be evolved and should make available to the farmers.

4. Proper guidance should be provided to the pulse growers about the use of recommended practices and production techniques.

5. Quality inputs like improved seeds, adequate credit facility must be available timely and at village level (sometimes even at block levels)

6. Adequate storage facilities should be provided to the farmers, to spread the sale throughout the year with minimum quantitative and qualitative losses.

\section{Way forward for improving marketing of pulses}

1. Improved quality standards; The market is changing and overseas traders increasingly demand strict adherence to product specifications

2. Value demands: Value addition is a term frequently used while discussing the future profitability of agriculture.

3. Processing and Grading of Pulses: The farmers generally sell pulses in an unprocessed form while they are consumed mostly in processed form. The most common type is dal.

4. Packing and Branding of Pulses: packaging is an important element in the entire process of marketing, attention is focused on attaining high standards.

5. Innovative Uses of Pulses: Pulse crops have a potential in snack food industry. Many varieties offer a good base for extended product as they produce a good flavor.

6. Semi Cooked, Ready to Eat Pulses: Fast food development, precooking and proper packaging are keys to sales in ready to cook and eat market. This is a specialty market but with appropriate scientific backing it could be profitable. Consumers want flavor, appearance, healthy, nutritional and ready to eat diet and many pulses can satisfy these requirements.

7. Scientific marketing:

a) Always bring the produce for sale after cleaning.

b) Sell different qualities of pulses separately.

c) Sell the pulses after grading.

d) Keep abreast of prevailing prices.

e) Avoid immediate post harvest sales

\section{Conclusions}

Focus should be made on providing the market information like prices, arrivals etc. to the farmers through SMS. Procurement of pulses must be done by some institution like HAFED, NAFED etc. especially in the peak market period of respective pulse commodities. An improvement in production technology of pulses aiming towards yield improvement and resource conservation can certainly reduce the cost of production and in turn prices may lead to balancing nutritional intake by reducing disproportionate use of cereals in the consumption basket. Improvement in extension activities of pulse productions is the root solution of the problems. 


\section{References}

1. Acharya SS, Agarwal NL. Agricultural marketing in India, Oxford and IBH publishing. 2004.

2. Anonymous. Statistical Abstract of Haryana. Economic and Statistical Organization, Planning Department, Government of Haryana, Chandigarh, (2015-16).

3. Anonymous. FAO Production Year Book, Food and Agriculture Organization, Rome, 2015.

4. Anonymous. Package of Practices for Kharif crops, Directorate of Publication, CCS Haryana Agicultural University, Hisar, 2015.

5. Autha D., Constraints and Techniques for Improving Pulses Production in Tamil Nadu, India. International Journal of Bioresource and Stress Management. 2011; 2(2):159-162.

6. Avinash CS, Chavan R, Kumar S, Sidramayya. Pulse Industry in India: Status and Way Forward -A Review. Trends in Biosciences. 2014; 7(18):2591-2595).

7. Shashikant VG, Prabhakar I, Manjunatha BL. Constraints in Production and Marketing of Redgram in Gulbarga District of Karnataka. Journal of Community Mobilization and Sustainable Development. 2011; 6(2):202-204. 